\title{
A misplaced window
}

\author{
Miguel F Carrascosa, ${ }^{1}$ Adelia G Menéndez, ${ }^{2}$ Lorenzo A Vega, ${ }^{2}$ Rubén G Izquierdo ${ }^{3}$
}

1Department of Internal Medicine, Hospital of Laredo, Laredo, Cantabria, Spain;

2Emergency Department, Hospital of Laredo, Laredo, Cantabria, Spain;

${ }^{3}$ Cardiology Department, Hospital of Laredo, Laredo, Cantabria, Spain

Correspondence to Dr Miguel F Carrascosa, miguel.carrascosa@scsalud.es

\section{DESCRIPTION}

In December 2011, an 83-year-old thin woman was referred to our emergency department because of 'a thoracic cutaneous abnormality'. In 2001, a permanent pacemaker had been implanted due to symptomatic sick sinus syndrome. Since then, she had remained well. Thirteen days before admission, a routine control assessment performed at pacemaker clinic displayed clinical and electrical normal findings. On admission, physical examination was remarkable for the presence of two lesions in the skin lied just above the generator (figure 1). The first was ulceration with slight perilesional erythema and the second consisted on isolated erosion which let us directly see the generator. White cell blood count and erythrocyte sedimentation rate were within normal limits and blood cultures were negative. Complete device removal, pocket cleaning and closure, and reimplantation of a new pacemaker on the left-sided subpectoral region were carried out. As there were signs of pocket infection only, she was on antibiotic therapy for 14 days. Outcome was favourable. With an increasing number of indications for implantation of cardiac devices and considering that incidence rates of cardiac device infections usually range from $0.13 \%$ to $19.9 \%$ for permanent pacemaker, ${ }^{1}$ clinicians can have the possibility to deal with this kind of condition in their common practice. Although ulceration of foreign bodies is not unusual, pacemaker infection presented as skin ulceration and erosion seems to be a rare event. ${ }^{12}$ The pathogenesis of these disorders may include local infection and continuous pressure of the hard device against the overlying subcutaneous and cutaneous structures, ${ }^{12}$ with ensuing development of tissue ischaemia and necrosis (like occur in other pressure ulcer cases). ${ }^{3}$ Besides subsequent infectious complications, device erosion can result in loss of pacing. ${ }^{4}$ Cure of cardiac device infections is possible in most patients with an approach that involves device extraction and antimicrobial therapy.1,2 4

Competing interests None.

Patient consent Obtained.

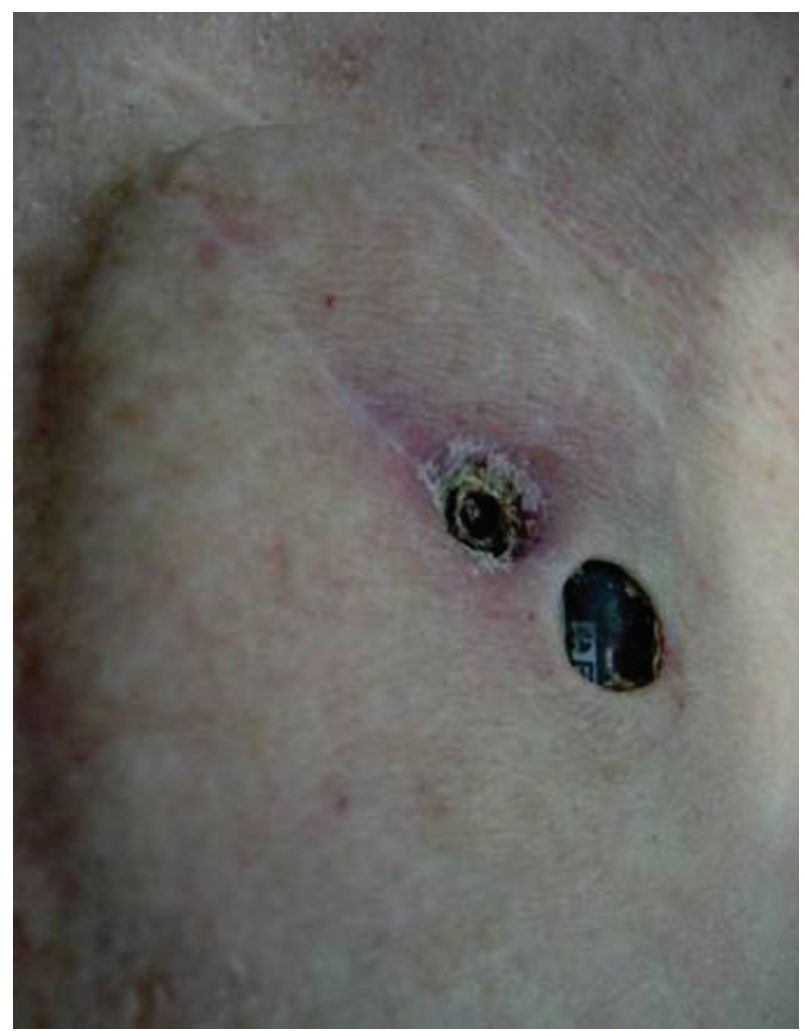

Figure 1 Eroded pacemaker. The generator is partially visible through an abnormal 'window'.

\section{REFERENCES}

1. Sohail MR, Uslan DZ, Khan AH, et al. Management and outcome of permanent pacemaker and implantable cardioverter-defibrillator infections. J Am Coll Cardiol 2007;49:1851-9.

2. Hamada M, Kayashima M, Uryu M, et al. Pressure cutaneous ulcer over a pacemaker successfully treated with left subcostal transplantation in an extremely thin patient. J Dermato/ 2006;33:567-70.

3. Topman G, Lin FH, Gefen A. The influence of ischemic factors on the migration of cell types involved in cutaneous and subcutaneous pressure ulcers. Ann Biomed Eng 2012 (In Press).

4. McCaw EH, Ristow B, Hongo R. Eroded pacemaker in an elderly patient. Am J Med 2010;123:e5-6. 


\section{BMJ Case Reports}

This pdf has been created automatically from the final edited text and images.

Copyright 2012 BMJ Publishing Group. All rights reserved. For permission to reuse any of this content visit http://group.bmj.com/group/rights-licensing/permissions.

BMJ Case Report Fellows may re-use this article for personal use and teaching without any further permission.

Please cite this article as follows (you will need to access the article online to obtain the date of publication).

Carrascosa MF, Menéndez AG, Vega LA, Izquierdo RG. A misplaced window. BMJ Case Reports 2012;10.1136/bcr.03.2012.5965, Published XXX

Become a Fellow of BMJ Case Reports today and you can:

- Submit as many cases as you like

- Enjoy fast sympathetic peer review and rapid publication of accepted articles

- Access all the published articles

- Re-use any of the published material for personal use and teaching without further permission

For information on Institutional Fellowships contact consortiasales@bmjgroup.com

Visit casereports.bmj.com for more articles like this and to become a Fellow

Keep up to date with all published cases by signing up for an alert (all we need is your email address) http://casereports.bmj.com/cgi/alerts/etoc 